\title{
Acceleration of Electroreduction Reaction of Water-Soluble Selenium Compounds in the Presence of Methyl Viologen
}

\section{Fumiya KOSHIKUMO, Wakana MURATA, Akiyuki OOYA, and Shin-ichiro IMABAYASHI*}

\author{
Department of Applied Chemistry, Shibaura Institute of Technology, \\ 3-7-5 Toyosu, Koto-ku, Tokyo 135-8548, Japan
}

* Corresponding author: s-imaba@shibaura-it.ac.jp

\begin{abstract}
The addition of methyl viologen $\left(\mathrm{MV}^{2+}\right)$ accelerates the reduction of $\mathrm{Na}_{2} \mathrm{SeO}_{3}$ not only in 0.1 mol dm $\mathrm{m}^{-3}$ sodium phosphate buffer (PBS, pH 7) but also in $0.22 \mathrm{~mol} \mathrm{dm}^{-3}$ sodium acetate buffer $(\mathrm{pH} 4)$. Water-insoluble red Se is dispersed in the vicinity of the electrode surface as the reduced product. Michaelis-Menten-type relationship is obtained between the reduction current and the concentration of $\mathrm{Na}_{2} \mathrm{SeO}_{3}$, suggesting that $\mathrm{MV}^{2+}$ molecules mediate the electron transfer from the electrode to $\mathrm{HSeO}^{-}$or $\mathrm{SeO}_{3}{ }^{2-}$ dissolved in $\mathrm{PBS}$. $\mathrm{MV}^{2+}$ is also effective in accelerating the reduction of $\mathrm{SeO}_{4}{ }^{2-}$, which has already been reported to be electrochemically inactive.
\end{abstract}

(c) The Electrochemical Society of Japan, All rights reserved.

Keywords : Water-Soluble Selenium Compounds, Electrochemical Reduction, Methyl Viologen, Mediation Reaction

\section{Introduction}

The demand for various elements, especially rare metals and metalloids, is continuously rising. Se is one such element and it is important ingredient in the production of photoelectric devices, photosensitive drums used in dry copying, and semi-conductors. $\mathrm{Se}$ is also an important trace element from environmental and biological points of view; however its intake as a nutrient should be restricted to very narrow concentration range: its intake outside this range leads to deficiency or toxicity. ${ }^{1}$ Se has several oxidation states in the environment, i.e., selenate $(+6)$, selenite $(+4)$, elemental Se $(0)$, and selenide $(-2)$. Human activities such as petroleum refining, mining and fossil fuel combustion result in the environmental contamination because of the formation of selenate $\left(\mathrm{SeO}_{4}{ }^{2-}\right)$ or/and selenite $\left(\mathrm{SeO}_{3}{ }^{2-}\right)$. These water-soluble oxyanions are the primary forms of Se in aerated environments. In Japan, it has been mandated by the government that the total $\mathrm{Se}$ concentration in industrial Se-contaminated wastewater should not exceed $0.1 \mathrm{mg}$ of $\mathrm{Se}$ in $1 \mathrm{dm}^{-3}$ because of the toxicity of these ions. While physicochemical methods including ion exchange, ferrihydrite adsorption/precipitation, and chemical reduction by zero valent iron, are generally applied for Se removal from wastewater, ${ }^{2}$ these methods are not suitable for Se recycling, which are rather expensive for practical use in industries. Biological treatments are promising alternative techniques to detoxify the water-soluble forms of Se to less toxic and insoluble elemental form. ${ }^{2}$ However, they are not applicable for industrial wastewaters containing relatively high concentrations of Se at various $\mathrm{pH}$ and salinity values.

The electrochemistry of $\mathrm{Se}$ is important in diverse contexts ranging from the chemical analysis of environmental samples ${ }^{3}$ to electrochemical co-deposition to grow compound semiconductors. ${ }^{4}$ In aqueous solutions, only two oxidation states of $\operatorname{Se}(-2)$ and $\mathrm{Se}(+4)$ exhibit electrochemical activity, ${ }^{5}$ whereas $\mathrm{Se}(+6)$ does not undergo reduction on mercury electrodes. ${ }^{6}$ In addition, the reduction of $\mathrm{Se}(+4)$ is accompanied by fairly high overpotential values. The present paper reports the reduction behavior of water-soluble Se oxyanions in the presence of methyl viologen $\left(\mathrm{MV}^{2+}\right)$. We found that the addition of $\mathrm{MV}^{2+}$ accelerates the electrochemical reduction of not only $\mathrm{SeO}_{3}{ }^{2-}$ but also $\mathrm{SeO}_{4}{ }^{2-}$ in both acidic and neutral aqueous conditions. Red precipitates or colloids of Se are generated as the reduction products, suggesting the possibility of electrochemical treatment for Se-containing wastewater.

\section{Experimental}

Sodium selenite $\left(\mathrm{Na}_{2} \mathrm{SeO}_{3}\right)$, sodium selenate $\left(\mathrm{Na}_{2} \mathrm{SeO}_{4}\right), \mathrm{N}, \mathrm{N}^{\prime}$ dimethyl-4,4'-bipyridinium dichloride $\left(\mathrm{MV}^{2+}\right)$, and all other chemicals were of reagent grade and used as received.

All electrochemical measurements were carried out in a conventional three-electrode cell equipped with a glassy carbon working electrode (GCE, geometric area $0.071 \mathrm{~cm}^{2}$ ), a Pt coil counter electrode, and a $\mathrm{Ag} \mid \mathrm{AgCl}$ (saturated $\mathrm{KCl}$ ) reference electrode. The surface of GCE was polished with $0.05-\mu \mathrm{m}$ alumina particle suspension on a moistened polishing cloth prior to use. Cyclic voltammograms $(\mathrm{CVs})$ were measured using a potentiostat $\mathrm{HZ} 5000$ (Hokuto Denko) at $25^{\circ} \mathrm{C}$ in $0.1(1.0,0.01) \mathrm{mol} \mathrm{dm}^{-3}$ sodium phosphate buffer (PBS, pH 7) or $0.22 \mathrm{~mol} \mathrm{dm}^{-3}$ acetate buffer (pH 4) deaerated by Ar bubbling.

\section{Results and Discussion}

\subsection{Reduction of $\mathrm{Se}(+4)$ in the absence of $\mathrm{MV}^{2+}$}

Figure 1 shows $\mathrm{CVs}$ for the reduction of $\mathrm{Se}(+4)$ species measured at GCE in neutral and acidic aqueous solutions. In $0.1 \mathrm{~mol} \mathrm{dm}^{-3} \mathrm{PBS}(\mathrm{pH} 7$ ), the reduction current started to increase at $-0.5 \mathrm{~V}$ for $30.1 \mathrm{mmol} \mathrm{dm}^{-3} \mathrm{Na}_{2} \mathrm{SeO}_{3}$, whereas no apparent reduction current appeared for $4.0 \mathrm{mmol} \mathrm{dm}{ }^{-3} \mathrm{Na}_{2} \mathrm{SeO}_{3}$. Compared with the $\mathrm{CVs}$ at $\mathrm{pH} 7$, the reduction current in $0.22 \mathrm{~mol} \mathrm{dm}^{-3}$ acetate buffer ( $\mathrm{pH}$ 4) containing $4.0 \mathrm{mmol} \mathrm{dm}^{-3} \mathrm{Na}_{2} \mathrm{SeO}_{3}$ increased with a shift in its onset potential to $-0.3 \mathrm{~V}$. Further increasing the $\mathrm{Na}_{2} \mathrm{SeO}_{3}$ concentration to $30.1 \mathrm{mmol} \mathrm{dm}^{-3}$ resulted in a decrease in the reduction current due probably to the deposition of the insulating red Se on the electrode surface. According to the acid-base equilibria (1) and (2) (written below), $\mathrm{HSeO}_{3}{ }^{-}$is dominant at $\mathrm{pH} 4$, whereas at $\mathrm{pH}$ 7, a mixture of $\mathrm{HSeO}_{3}{ }^{-}$and $\mathrm{SeO}_{3}{ }^{2-}$ exists. The difference in the reduction onset potential between $\mathrm{pH} 4$ and 7 can be explained by the $\mathrm{pH}$ dependence of redox potentials for the reactions (3) and (4). In addition, high overpotentials for these reductions are confirmed from the fact that the onset potentials at $\mathrm{pH} 4$ and 7 are more 


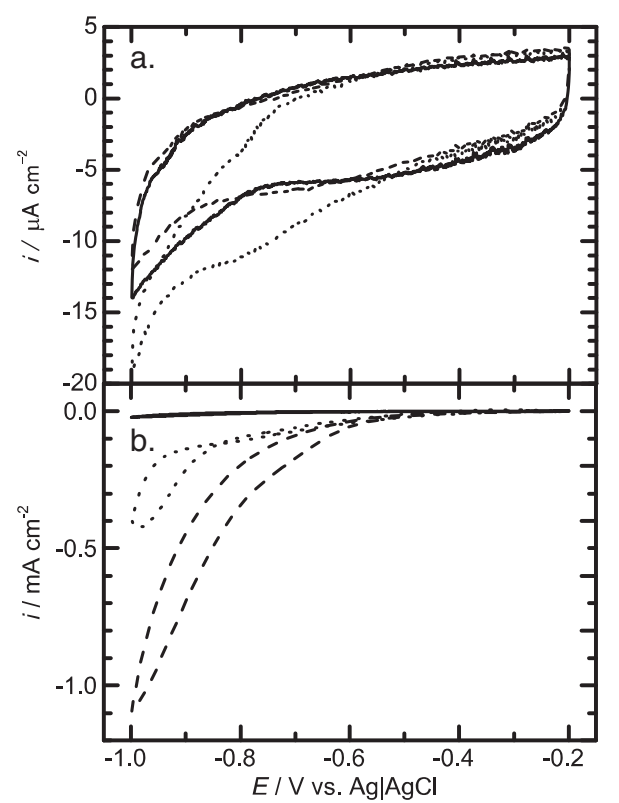

Figure 1. Cyclic voltammograms measured at glassy carbon working electrode (GCE) in (a) $0.1 \mathrm{~mol} \mathrm{dm}^{-3}$ sodium phosphate buffer (PBS) (pH 7) and (b) $0.22 \mathrm{~mol} \mathrm{dm}^{-3}$ acetate buffer (pH 4) containing 0 (solid line), 4.0 (dashed line), and 30.1 (dotted line) $\mathrm{mmol} \mathrm{dm}{ }^{-3}$ of $\mathrm{Na}_{2} \mathrm{SeO}_{3}$.

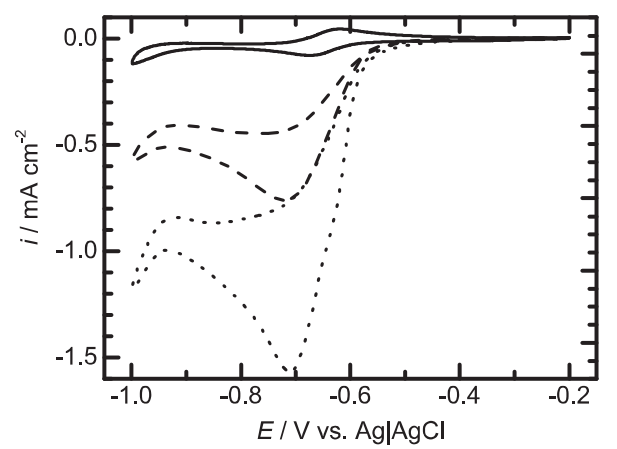

Figure 2. Cyclic voltammograms measured at GCE in 0.1 moldm ${ }^{-3}$ PBS (pH 7) containing $1 \mathrm{mmol} \mathrm{dm}^{-3}$ methyl viologen $\left(\mathrm{MV}^{2+}\right)$ and 0 (solid line), 4.0 (dashed line), and 30.1 (dotted line) mmol dm ${ }^{-3}$ of $\mathrm{Na}_{2} \mathrm{SeO}_{3}$.

negative than the redox potentials of reactions (3) and (4) at the corresponding $\mathrm{pH}$ values.

$$
\begin{aligned}
& \mathrm{H}_{2} \mathrm{SeO}_{3} \leftrightarrows \mathrm{HSeO}_{3}{ }^{-}+\mathrm{H}^{+} \quad(\mathrm{p} K=2.46 \text { or } 2.57)^{5,7} \\
& \mathrm{HSeO}_{3}{ }^{-} \leftrightarrows \mathrm{SeO}_{3}{ }^{2-}+\mathrm{H}^{+} \quad(\mathrm{p} K=6.58 \text { or } 7.31)^{5,7} \\
& \mathrm{HSeO}_{3}{ }^{-}+5 \mathrm{H}^{+}+4 \mathrm{e}^{-}=\mathrm{Se}+3 \mathrm{H}_{2} \mathrm{O} \\
&(E=0.579-0.074 \mathrm{pH} \mathrm{V} \text { vs. } \mathrm{Ag} \mid \mathrm{AgCl}) \\
& \mathrm{SeO}_{3}{ }^{2-}+ 6 \mathrm{H}^{+}+4 \mathrm{e}^{-}=\mathrm{Se}+3 \mathrm{H}_{2} \mathrm{O} \\
&(E=0.676-0.089 \mathrm{pH} \mathrm{V} \text { vs. } \mathrm{Ag} \mid \mathrm{AgCl})
\end{aligned}
$$

\subsection{Reduction of $\mathrm{Se}(+4)$ in the presence of $\mathrm{MV}^{2+}$}

The addition of $1 \mathrm{mmol} \mathrm{dm}^{-3} \mathrm{MV}^{2+}$ accelerated the reduction of $\mathrm{Se}(+4)$ by more than 500 times at $\mathrm{pH} 7$ (Fig. 2). During the reduction, water-insoluble red Se was dispersed in the vicinity of the GCE surface. The onset potential of the reduction current coincides with that of the $\mathrm{MV}^{2+}$ reduction. As shown in Fig. 3, MichaelisMenten-type plots were obtained for the relationship between the magnitude of the current increment $(\Delta i)$ and the concentration of

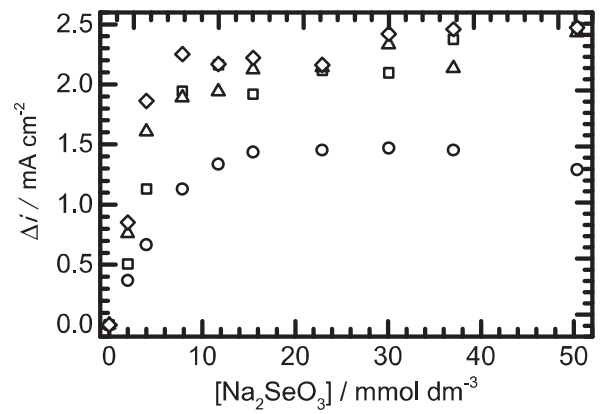

Figure 3. Magnitude of the current increase $(\Delta i)$ as a function of the concentration of $\mathrm{Na}_{2} \mathrm{SeO}_{3}$ in the presence of $1.0(\bigcirc), 5.0(\square), 10$ $(\triangle)$, and $20(\diamond) \mathrm{mmol} \mathrm{dm}^{-3}$ of $\mathrm{MV}^{2+}$.

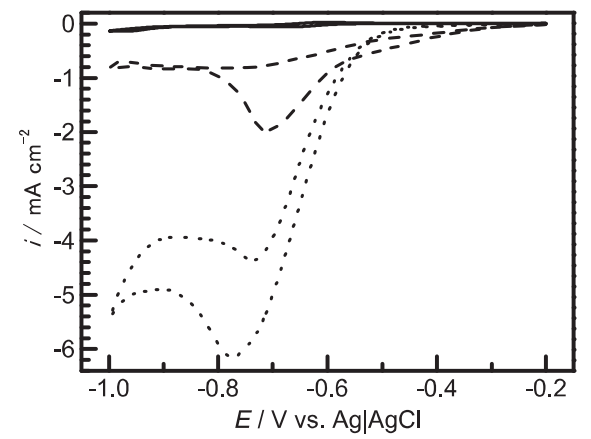

Figure 4. Cyclic voltammograms measured at GCE in 0.22 moldm ${ }^{-3}$ acetate buffer ( $\left.\mathrm{pH} 4\right)$ containing $1 \mathrm{mmol} \mathrm{dm}^{-3} \mathrm{MV}^{2+}$ and 0 (solid line), 4.0 (dashed line), or 30.1 (dotted line) $\mathrm{mmol} \mathrm{dm}^{-3}$ of $\mathrm{Na}_{2} \mathrm{SeO}_{3}$.

$\mathrm{Na}_{2} \mathrm{SeO}_{3}$, where the $\Delta i$ value increased with the concentration of $\mathrm{Na}_{2} \mathrm{SeO}_{3}$ and leveled off above $15 \mathrm{mmoldm}^{-3}$. The $\Delta i$ value increased by 1.4 times when the concentration of $\mathrm{MV}^{2+}$ was increased from 1 to $5 \mathrm{mmol} \mathrm{dm}^{-3}$; however, no further increase was observed at concentration above $5 \mathrm{mmol} \mathrm{dm}^{-3}$. Although the acceleration mechanism is not fully understood, the MichaelisMenten-type plots suggest that $\mathrm{MV}^{2+}$ mediates the electron transfer from $\mathrm{GCE}$ to $\mathrm{Se}(+4)$ dissolved in PBS.

The $\mathrm{Se}(+4)$ reduction also accelerated in $0.22 \mathrm{~mol} \mathrm{dm}^{-3}$ sodium acetate buffer $(\mathrm{pH} 4)$ as shown in Fig. 4 . Greater $\Delta i$ values and a positive shift in the onset potential of $\mathrm{Na}_{2} \mathrm{SeO}_{3}$ reduction were observed in comparison to $\mathrm{pH} 7$, which is attributable to the positive shift in the redox potentials of reactions (3) and (4) on decreasing the $\mathrm{pH}$. Based on the potential range where the reduction current increases, large $\Delta i$ is likely to be originated from the mediation by $\mathrm{MV}^{2+}$. However, for $4.0 \mathrm{mmoldm}^{-3} \mathrm{Na}_{2} \mathrm{SeO}_{3}$, the potential at which the reduction current begins to flow is more positive than that for $\mathrm{MV}^{2+}$, suggesting at the coexistence of other acceleration mechanisms in addition to the mediation by $\mathrm{MV}^{2+}$. In contrast, the acceleration of $\mathrm{Se}(+4)$ reduction did not occur at $\mathrm{pH} 9$ (data not shown), where $\mathrm{SeO}_{3}{ }^{2-}$ is the main $\mathrm{Se}(+4)$ species. Our recent measurements ${ }^{8}$ suggest that the difference between the redox properties of $\mathrm{HSeO}_{3}{ }^{-}$and $\mathrm{SeO}_{3}{ }^{2-}$ reflects the $\mathrm{pH}$ dependence of the acceleration.

Figure 5 represents the effect of the concentration of PBS ( $\mathrm{pH} 7)$ on the $\Delta i$ value in the presence of $1 \mathrm{mmol} \mathrm{dm}^{-3} \mathrm{MV}^{2+}$. The greater magnitude of acceleration was obtained at higher concentrations of PBS. At $0.01 \mathrm{~mol} \mathrm{dm}^{-3} \mathrm{PBS}$, the $\Delta i-\left[\mathrm{Na}_{2} \mathrm{SeO}_{3}\right]$ plot revealed a maximum $\Delta i$ value of approximately $4.0 \mathrm{mmol} \mathrm{dm}^{-3}$, in contrast to the plots at 0.1 and $1.0 \mathrm{~mol} \mathrm{dm}-3$ PBS. When $\mathrm{Na}_{2} \mathrm{SeO}_{3}$ is added into PBS, the concentration of $\mathrm{H}^{+}(\mathrm{pH})$ changes through the acid-base equilibrium (2) and the reductions (3) and (4). Because of the lower 


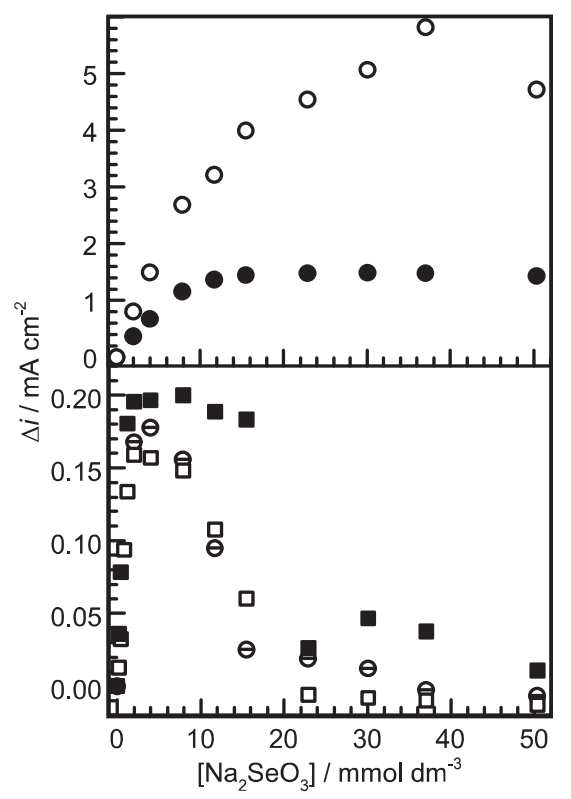

Figure 5. Magnitude of the current increase $(\Delta i)$ as a function of the concentration of $\mathrm{Na}_{2} \mathrm{SeO}_{3}$ in the presence of $1.0 \mathrm{mmol} \mathrm{dm}^{-3}$ of $\mathrm{MV}^{2+}$ in $0.01(\ominus), 0.1(\bullet)$, and $1.0(\bigcirc) \mathrm{mol} \mathrm{dm}^{-3} \mathrm{PBS}(\mathrm{pH} 7)$. To examine the effect of ionic strength on the reduction current, the ionic strength of $0.01 \mathrm{~mol} \mathrm{dm}^{-3}$ PBS was increased to $0.22(\square)$ and 2.2 (ם) $\mathrm{mol} \mathrm{dm}^{-3}$ by adding an appropriate amount of $\mathrm{NaCl}$.

buffer capacity of $0.01 \mathrm{~mol} \mathrm{dm}^{-3} \mathrm{PBS}$, the $\mathrm{pH}$ value increases with the addition of $\mathrm{Na}_{2} \mathrm{SeO}_{3}$. This is the reason for the formation of the convex plot, because the magnitude of acceleration becomes lower with increasing $\mathrm{pH}$, as mentioned above. The ionic strength of PBS changes concomitantly with its concentration. In order to examine the effect of ionic strength on the acceleration of reduction, the ionic strength of $0.01 \mathrm{~mol} \mathrm{dm}^{-3}$ PBS $\left(0.022 \mathrm{~mol} \mathrm{dm}^{-3}\right)$ was raised to 0.22 or $2.2 \mathrm{~mol} \mathrm{dm}^{-3}$ by adding appropriate amount of $\mathrm{NaCl}$. The shapes of the resulting $\Delta i-\left[\mathrm{Na}_{2} \mathrm{SeO}_{3}\right]$ plots were similar to that obtained with the original $0.01 \mathrm{~mol} \mathrm{dm}^{-3}$ PBS and independent of the ionic strength. The electrochemical reduction of $\mathrm{Na}_{2} \mathrm{SeO}_{3}$ mediated by $\mathrm{MV}^{2+}$ consists of two steps: (1) the reduction of $\mathrm{MV}^{2+}$ to $\mathrm{MV}^{+}$at the electrode surface, and (2) the reduction of $\mathrm{Se}(+4)$ to $\mathrm{Se}(0)$ by $\mathrm{MV}^{+}$in the buffer solution. The shape and magnitude of $\mathrm{CV}$ for the $\mathrm{MV}^{2+/+}$ redox couple were independent of the PBS concentration, showing that the PBS concentration is likely to affect the latter step. Since protons are included in the reductions (3) and (4), the higher buffer capacity (higher buffer concentration) seems to be decisive in achieving greater acceleration.

\subsection{Reduction of $\mathrm{Se}(+6)$ in the presence of $\mathrm{MV}^{2+}$}

The addition of $\mathrm{MV}^{2+}$ is also effective in accelerating the reduction of $\mathrm{Se}(+6)$, which has been reported to be electrochemically inactive, ${ }^{6}$ under both neutral and acidic conditions (Fig. 6). According to the $\mathrm{p} K$ values for the acid-base equilibria of $\mathrm{H}_{2} \mathrm{SeO}_{4}{ }^{5}$ $\mathrm{SeO}_{4}{ }^{2-}$ is the main redox component at $\mathrm{pH} 4$ and 7 . In spite of the fact that the redox potentials for the reduction reactions of $\mathrm{SeO}_{4}{ }^{2-}$, (5) and (6), are more positive than those for the reduction of $\mathrm{Se}(+4)$, the magnitude of acceleration is lower for $\mathrm{SeO}_{4}{ }^{2-}$ than for $\mathrm{Se}(+4)$, suggesting more sluggish nature of the $\mathrm{MV}^{2+}$-mediated reduction of $\mathrm{SeO}_{4}^{2-}$.

$$
\begin{aligned}
& \mathrm{SeO}_{4}{ }^{2-}+ 3 \mathrm{H}^{+}+2 \mathrm{e}^{-}=\mathrm{HSeO}_{3}{ }^{-}+\mathrm{H}_{2} \mathrm{O} \\
&(E=0.876-0.089 \mathrm{pH} \text { V vs. } \mathrm{Ag} \mid \mathrm{AgCl}) \\
& \mathrm{SeO}_{4}{ }^{2-}+ 2 \mathrm{H}^{+}+2 \mathrm{e}^{-}=\mathrm{SeO}_{3}{ }^{2-}+\mathrm{H}_{2} \mathrm{O} \\
&(E=0.681-0.059 \mathrm{pH} \text { V vs. } \mathrm{Ag} \mid \mathrm{AgCl})
\end{aligned}
$$

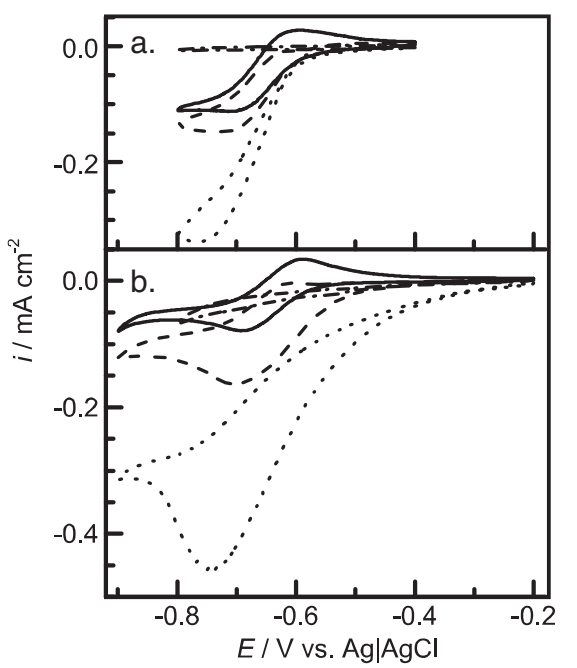

Figure 6. Cyclic voltammograms (CVs) measured at GCE in (a) $0.1 \mathrm{~mol} \mathrm{dm}^{-3}$ PBS (pH 7) and (b) $0.22 \mathrm{~mol} \mathrm{dm}^{-3}$ acetate buffer (pH 4) containing $1 \mathrm{mmol} \mathrm{dm}^{-3} \mathrm{MV}^{2+}$ and 0 (solid line), 30 (dashed line), or 117 (dotted line) $\mathrm{mmol} \mathrm{dm}^{-3}$ of $\mathrm{Na}_{2} \mathrm{SeO}_{4}$. CVs measured for $117 \mathrm{mmol} \mathrm{dm}^{-3}$ of $\mathrm{Na}_{2} \mathrm{SeO}_{4}$ in the same buffer solutions in the absence of $\mathrm{MV}^{2+}$ are also shown (dashed-dotted line).

\section{Conclusions}

$\mathrm{MV}^{2+}$ is able to accelerate the reduction of water-soluble $\mathrm{Se}(+4)$ and $\mathrm{Se}(+6)$ species. The greatest magnitude of acceleration (more than 500 times) was obtained for the reduction of $\mathrm{Na}_{2} \mathrm{SeO}_{3}$ in $0.1 \mathrm{~mol} \mathrm{dm}^{-3} \mathrm{PBS}(\mathrm{pH} 7)$ in the presence of $5 \mathrm{mmol} \mathrm{dm}^{-3} \mathrm{MV}^{2+}$. The Michaelis-Menten-type relationships between the reduction current and the concentration of $\mathrm{Na}_{2} \mathrm{SeO}_{3}$ indicate that $\mathrm{MV}^{2+}$ molecules mediate the electron transfer from the electrode to $\mathrm{Se}(+4)$ dissolved in buffer solutions. Benzyl viologen, heptyl viologen, and alizarin red $\mathrm{S}$ (data not shown) are also effective in accelerating the reduction of $\mathrm{Na}_{2} \mathrm{SeO}_{3}$, although the magnitude of acceleration is the highest for $\mathrm{MV}^{2+}$. The properties of the mediator required for effective acceleration are yet to be clarified. It is suggested that high buffer capacity is important to achieve greater acceleration. Red precipitates or colloids of Se are generated as the reduction products, which will be useful for recycling of Se from Se-containing wastewaters. Detailed analysis of the acceleration mechanism is still under investigation.

\section{Acknowledgment}

This work is partly supported by Grant-in-Aid for Scientific Research (c) (24510106 for S.I.) from the Ministry of Education, Culture, Sports, Science and Technology, Japan.

\section{References}

1. S. B. Goldhaber, Regul. Toxicol. Pharmacol., 38, 232 (2003).

2. M. Lenz and P. N. L. Lens, Sci. Total Environ., 407, 3620 (2009).

3. T. Ferri and P. Sangiorgio, Anal. Chim. Acta, 385, 337 (1999).

4. J. L. Stickney, Electroanalytical Chemistry, Vol. 21 (Eds. A. J. Bard and I. Rubinstein), Marcel Dekker, New York, p. 75 (1999).

5. S. I. Zhdanov, Encyclopedia of Electrochemistry of the Elements, Vol. IV (Ed. A. J. Bard), Marcel Dekker, New York, Ch. 7 (1974).

6. J. J. Lingane and L. W. Niedrach, J. Am. Chem. Soc., 71, 196 (1949).

7. M. Bouroushian, T. Kosanovic, Z. Loizos, and N. Spyrellis, Electrochem. Commun., 2, 281 (2000).

8. Manuscript in preparation. 